\title{
Multiculturalism as One of the Primary Determinants of Growth
}

\author{
Błażej Balewski, Małgorzata Franaszek \\ Higher School of Personnel Management in Konin, Konin, Poland
}

\begin{abstract}
The main objective of the project "Determinants of Socio-economic Development in Eastern Wielkopolska Region in the Second Half of the 19th and the First Half of the 20th Century" is to understand factors affecting the socio-economic development of the former Eastern Wielkopolska region and exploring its possible connection with activity of foreign ethnical cultures. At the first stage of the project's fulfillment, contact has been made with the Federation of Expellees, consulate of Russia in Poznan and the administration of Jewish communities in Poland. Hitherto, researchers' attention has been focused mainly on clear defining of the essence of development according to various economic doctrines, carrying out literature studies concerning the actual state of knowledge in the subject of influence of national minorities and multiculturalism on the development of the eastern lands of Wielkopolska during the period 1864-1968. Implementation of the project promotes the spirit of historical truth and spirit of tolerance and respect for people of other cultures and religions.
\end{abstract}

Keywords: multiculturalism, development, nationality, anti-Semitism

פולין (pol in), Polen, Польша ${ }^{1}$, although the names sound differently, they denote the same place on earth; it was once home to Russian, German, and Hebrew speakers, who alongside Poles, helped the country grow with the products of their talent and work. Here is where many of them were buried. Out of here many of them were cast out. Unfortunately, their migrations were followed by the elimination of information concerning their contributions to the socioeconomic development of Polish lands, both from the pages of history and collective memory. Striving to reflect reality in thought obligates researchers to make attempts at uncovering the local heritage of Jews, Russians, and Germans, i.e., the ethnic groups which used to populate individual Polish regions.

\section{Ethnic Structure in the Eastern Wielkopolska in the 18th Century}

Since 1795, the Wielkopolska region remained under the influence of two states: Prussia and Russia. The Moscow Empire ruled over its eastern part, which was known at the time as the Kalisz Governorate (Gubernia Kaliska).

The ethnic structure of the population inhabiting this part of Wielkopolska (see Table 1), developed over hundreds of years, was heterogeneous. Almost $25 \%$ of this population was constituted by Jews, Germans, and Russians. On the brink of World War I, the latter constituted only $0.5 \%, 8.2 \%$ of the population was German,

Corresponding author: Błażej Balewski, Ph.D., Dean of Economic Faculty, Higher School of Personnel Management in Konin, Konin, Poland; research field: HRM effectiveness. E-mail: blazej@balewski.pl.

Małgorzata Franaszek, Ph.D., Dean of Humanistic Faculty, Higher School of Personnel Management in Konin, Konin, Poland; research fields: culture and communication. E-mail: m.franaszek@vp.pl.

${ }^{1}$ It says Poland in Hebrew, German, and Russian. It shows that Jews, Germans, and Russians lived in Poland and called it in their own languages. 
and $9.1 \%$ of the population was Jewish. This ethnic structure was not observed in cities and towns, considered by many economists to be the bulwark of growth and progress.

Over $40 \%$ of the inhabitants of the cities of Eastern Wielkopolska were Jewish, German, or Russian. Followers of Judaism constituted the largest group among them (see Table 2).

Table 1

Civilian Population of the Governorates of the Kingdom of Poland in 1913 With Respect to Native Language and Religious Denomination

\begin{tabular}{|c|c|c|c|c|c|c|c|c|}
\hline \multirow[b]{2}{*}{ Governorate } & \multicolumn{4}{|c|}{ Native language } & \multicolumn{4}{|c|}{ Religious denomination } \\
\hline & Polish & Other Slavic & Jewish & German & Catholicism & $\begin{array}{l}\text { Orthodox } \\
\text { Christianity }\end{array}$ & Protestantism & Judaism \\
\hline $\begin{array}{l}\text { All } \\
\text { governorates }\end{array}$ & 72.2 & 4.7 & 14.9 & 5.5 & 76.0 & 3.7 & 5.3 & 15.0 \\
\hline $\begin{array}{l}\text { Kalisz } \\
\text { Governorate }\end{array}$ & 82.3 & 0.5 & 9.0 & 8.2 & 82.1 & 0.5 & 8.3 & 9.1 \\
\hline
\end{tabular}

Note. Sources: the work based on Krzyżanowski and Kumaniecki (1915) ${ }^{2}$, Jezierski and Wyczański (2003)

Table 2

Population of Cities and Towns in the Kingdom of Poland in 1897 by Governorate With Respect to Religious Denomination

\begin{tabular}{llll}
\hline \multirow{2}{*}{ Governorate } & \multicolumn{2}{c}{ Religious denomination (\% of population) } \\
\cline { 2 - 4 } & Catholicism & Judaism & Other \\
\hline All governorates & 51.1 & 39.8 & 9.1 \\
Kalisz & 58.7 & 35.5 & 5.8 \\
Kielce & 49.0 & 49.4 & 1.6 \\
Lublin & 36.9 & 54.4 & 8.7 \\
Lomża & 37.4 & 57.5 & 5.1 \\
Piotrków & 55.7 & 29.6 & 14.7 \\
Płock & 54.9 & 40.3 & 4.8 \\
Radom & 45.1 & 51.1 & 3.8 \\
Siedlce & 33.7 & 56.5 & 9.8 \\
Suwałki & 43.3 & 40.5 & 16.2 \\
Warsaw & 56.6 & 35.4 & 8.1 \\
\hline
\end{tabular}

Note. Sources: based on Szulc (1920) ${ }^{4}$ and Nietyksza (1986) ${ }^{5}$.

The number of Jews, among all residents in that part of Poland, had been increasing till the moment of the early years of Israel's revival and escalating manifestation of anti-Semitism connected with thriving totalitarian ideologies, mostly the nationalist ideologies (see Figure 1).

${ }^{2}$ Statystyka Polska (Statistics of Poland). Kraków, pp. 46-49.

${ }^{3}$ Historia Polski w liczbach. Państwo spoleczeństwo (Economic history of Poland in numbers. State and society). Central Statistical Office, Warsaw, p. 186.

${ }^{4}$ Wartość materiałów statystycznych dotyczqcych stanu ludności b. Królestwa Polskiego (The value of statistical material pertaining to the population of the former Kingdom of Poland). Warsaw, 1920, pp. 146-182.

${ }_{5}$ Rozwój miast i aglomeracji miejsko-przemysłowych w Królestwie Polskim 1865-1914 (The development of cities and industrial urban agglomerations in the Kingdom of Poland 1865-1914), Warsaw, 1986, pp. 159, 217, 222, 239, 243, as quoted in: A. Jezierski and A. Wyczański (Ed.), Historia Polski w liczbach. Państwo społeczeństwo (Economic history of Poland in numbers. State and society). Central Statistical Office, Warsaw, 2003, p. 188. 


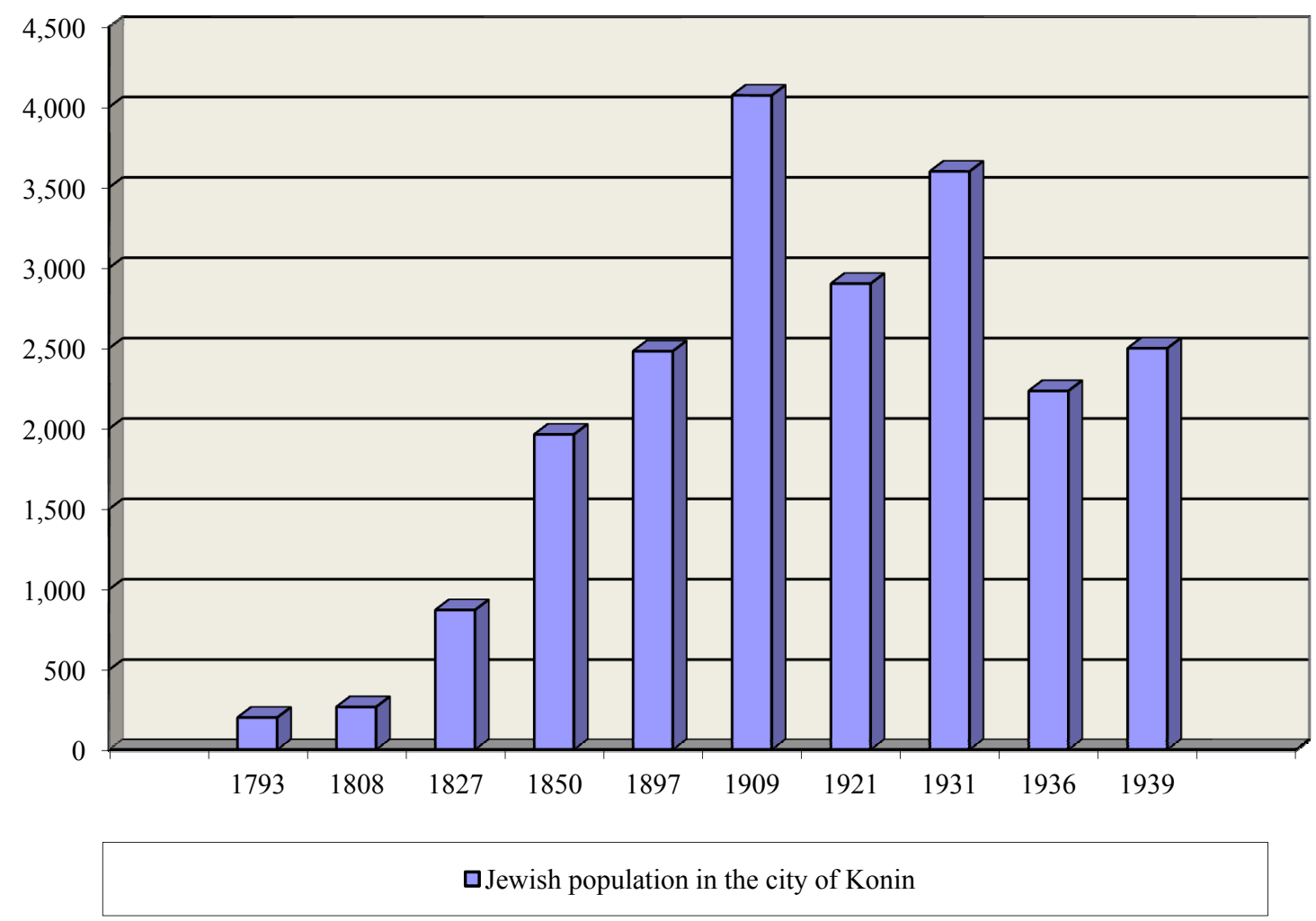

Figure 1. The Jewish population changes in Konin from 1793 to 1939. Source: see the website ${ }^{6}$.

\section{Examples of the Influence of the Jews, Germans, and Russians on the Socio-Economic Development}

Studying the subject literature, allows us to note that their contributions to socio-economic growth were more than significant. This can be corroborated by the fact that representatives of these groups were among the first to build granaries, mills, and semi-porcelain factories, providing construction and other services (see Table 3).

The authorities did not allow Jews to work on Sundays: They could not manage stores or other businesses in peace, as many considered them unwanted competition. Jews could not become state officials, police officers, or mail carriers. They could not own land. But each of them wanted to live. In order to live, they had to earn money. This is one of the reasons why Jews contributed to the development of trade and industry in Poland ${ }^{7}$.

Apart from Jews, Russians and Germans also contributed to the development of Wielkopolska. Analyzing the contribution of Germans in the development of the region, Dr. Paul Krische and Dr. Carl Riemann underscored that Poznan at the turn of the 20th century was a solely agricultural province (Krische \& Riemann, 2014). Transportation remained poorly developed and there were few roads. In 1895 , the region had only 3,975 $\mathrm{km}$ of roads: $137 \mathrm{~km}$ for every $1,000 \mathrm{~km}^{2}$, i.e., less than any other province of the Prussian monarchy. This impeded the development of industry. The 1950s turned out to be a relatively lively period in terms of industry. The following manufacturing facilities were active at the time: spinning mills (244), broadcloth factories (14),

\footnotetext{
${ }^{6}$ Retrieved from http://www.sztetl.org.pl/pl/article/konin/6,demografia/ (February 7, 2015).

7 Joskowicz, P. M. 1996. Opowieść o radości i cierpieniu (A tale of joy and suffering) (p. 41). Warsaw: Grupa Image.
} 
dye houses (124), printing houses (20), watermills (552), windmills (2,676), animal-powered mills (111), oil mills (285), fulling mills (37), mills for grinding oak bark (37), sawmills (81), paper factories (nine), steam machines in various factories (15), field beet sugar factories (six), snuff tobacco factories (26), breweries (309), distilleries (256), steel mills (nine), copper forges (three), machine factories (two), glassworks (14), vinegar factories (seven), lime works (80), brick factories (723), tar factories (66), cast-iron foundries (two), and salt works (one) (Krische \& Riemann, 2014, pp. 80-88).

Such conditions placed the Poznan region among the poorest provinces of the Prussian monarchy.

In his book, another German scholar, Dr. Wegener characterizes the economic condition of the province in the following manner:

(1) Poznan is a poor, predominantly agricultural province;

(2) The rural population is divided into social aristocratic groups. There is a difference between great landowners and small farmers;

(3) The cities lack leading bourgeois elites as artisan facilities are dominant, and the industry does not cross local boundaries;

(4) Although industry is present and noteworthy, it is almost solely a secondary rural economic activity (Krische \& Riemann, 2014, pp. 80-88).

The intellectual development of the region was also very poor. The province lacked universities, museums, and other scientific institutions worth noting. Its geographic location and the regrettable condition of the region's culture did not improve the situation. Furthermore, political strife in other provinces precluded the growth of Wielkopolska and led to intellectual neglect. In such circumstances, the Poznań Province achieved autonomy as late as 1889 . Notwithstanding, cultural life began to develop since 1875 , as subsidies were decreed for artistic and scientific challenges. Various scientific societies took part in this process, having been established some time before. They included the Society for Natural Sciences founded in 1837, which by 1875 , boasted 163 members including education specialists; it organized lectures and courses and published its own periodical since 1894. Another scientific association was the Polytechnic Society, founded in 1867 and counting 168 members. It tackled with technical questions concerning the province, including the regulation of the Warta River and the construction of flood walls, and established a Preparatory School of Artisanship in Poznań in 1869. These two groups were joined by the Singing Society founded in 1869, which oversaw oratories and solo concerts, as did the Posnanian Artistic Society since 1884. Ultimately, the strongest scientific group turned out to be the Province's Historical Society founded in 1885. It had a very good library and boasted 385 members in the city and 907 in the area. In 1894, the Historical Society came to an agreement with the province's authorities, based on which the first library was opened.

The other mentioned societies participated in projects serving the general good. The province ceded the building of the old headquarters on Wilhelmstrasse to the library, which featured 25,000 items. Thus, the National Library was established. Also by that time, a provincial museum was opened, featuring the collection of the Historical Society.

According to Paul Krische and Carl Riemann, the establishment of the museum was considered to be the second most important cultural factor. On February 25, 1889, the chamber of deputies allocated 900,000 marks for the construction of the museum, thus, a beautiful provincial museum was established at Wilhelmsplatz, presenting noteworthy prehistoric, cultural/historical, and natural science collections, as well as a proper collection of paintings. 
Table 3

The Contributions of the Jewish, German, and Russian Population in the Development of Koto

\begin{tabular}{|c|c|c|c|}
\hline Date & \begin{tabular}{|l}
$\begin{array}{l}\text { Socioeconomic achievements of the Jewish } \\
\text { population }\end{array}$ \\
\end{tabular} & $\begin{array}{l}\text { Socioeconomic achievements of the German } \\
\text { population }\end{array}$ & $\begin{array}{l}\text { Socioeconomic achievements of the Russian } \\
\text { population }\end{array}$ \\
\hline $1845-$ & Markin Hyman builds a wooden granary. & & \\
\hline 1846, April $9(21)^{8}$ & 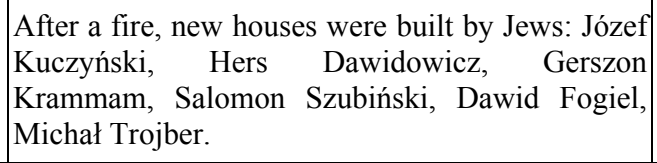 & & \\
\hline 1851-1852 & $\begin{array}{l}\text { The City Hall in Koło was repaired by a } \\
\text { construction company owned by Mojżesz Flatto } \\
\text { from Piotrków for the sum of } 1680 \text { silver rubles. }\end{array}$ & & \\
\hline 1856 & $\begin{array}{l}\text { Jakub Tejchfeld's semi-porcelain factory was } \\
\text { founded. }\end{array}$ & & \\
\hline 1867 & $\begin{array}{l}\text { Michał Zaucha established a steam mill in the } \\
\text { city. }\end{array}$ & & \\
\hline 1874 & The elementary school employed three teachers: KL & Kurczewski, Ernst, and Rozenblum. & \\
\hline 1879 & $\begin{array}{l}\text { A committee was selected in Koło in order to creat } \\
\text { administrators; its members included: Aleksander, } \\
\text { Schuppe (the county engineer), Leonard Zalewski }\end{array}$ & $\begin{array}{l}\text { ate a 4-year Realschule with an introductory year. Th } \\
\text { r, Count of Kreutz from Kościelec, Aleksander Kłot } \\
\text { (notary), and others. }\end{array}$ & $\begin{array}{l}\text { e committee was headed by Jakowlew, the county } \\
\text { bukowski (the owner of Powiercie and Zawadki), }\end{array}$ \\
\hline 1883 , February 4 & & & $\begin{array}{l}\text { On Sunday, the first Public Library in Koło was } \\
\text { ceremoniously opened. The initiator of its } \\
\text { establishment was the local justice of the peace } \\
\text { Matrosow, while Count Aleksander Kreutz } \\
\text { became its honorary founder. }\end{array}$ \\
\hline 1889, July & $\begin{array}{l}\text { In the village of Nagórna, Kuczyński founded an } \\
\text { embroidery factory (in the home of Ławnicki, a } \\
\text { master blacksmith). The factory was comprised of } \\
\text { three rooms and employed two men and three girls } \\
\text { (Jewish). }\end{array}$ & & \\
\hline 1890 & & & $\begin{array}{l}\text { A post/telegraph station was established in the } \\
\text { city. }\end{array}$ \\
\hline
\end{tabular}

${ }_{8}^{8}$ It means that at that time in Poland, two calendars (Julian and Gregorian) were used. 


\begin{tabular}{|l|l|l|l|}
\hline Date & $\begin{array}{l}\text { Socioeconomic achievements of the Jewish } \\
\text { population }\end{array}$ & $\begin{array}{l}\text { Socioeconomic achievements of the German } \\
\text { population }\end{array}$ & $\begin{array}{l}\text { Socioeconomic achievements of the Russian } \\
\text { population }\end{array}$ \\
\hline 1897 & $\begin{array}{l}\text { Mordka Goldberg founded a mechanical sawmill. } \\
\text { During this time, Koło was home to the mills of } \\
\text { Abraham Warbrun, Jakub Lewi, and Hersz } \\
\text { Danziger (company) as well as Hanin Neuman and } \\
\text { Icek Gutman; there were also the printing houses } \\
\text { of M. Rosentejn and E. Szwarcman. }\end{array}$ & \\
\hline 1910, January 5 & $\begin{array}{l}\text { Major industrial plants include: Borenstein's (1900), ceramic ware factory (Rauch, 90 workers), two } \\
\text { printing houses (M. Rosenstein and E. Szwarcman), and four mills. }\end{array}$ & \\
\hline 1910, January 5 & $\begin{array}{l}\text { Two dentists worked in the city: Szurlichter and Lipszyc. } \\
1911,\end{array}$ & $\begin{array}{l}\text { Aleksander, Count of Kreutz, chamberlain of the } \\
\text { court, the hereditary owner of the Kościelec estate, } \\
\text { a benefactor of the Realschule in Koło, the } \\
\text { constructor of the palace and founder of the park in } \\
\text { Kościelec, died at 8:00 a.m. }\end{array}$ & \\
\hline November 1 & & $\begin{array}{l}\text { Elementary education was provided in 84 schools with Polish as the language of instruction and 29 } \\
\text { schools with German as the language of instruction. Polish schools were attended by 4,779 children, } \\
\text { while 907 attended German schools. In Koło, there was a 6-year School of Trade and a 4-year Private } \\
\text { Girl's Boarding School. In the county, there were 30 active cheders (Jewish elementary religious } \\
\text { schools). In total, approximately 30\% of school-age children underwent elementary education. }\end{array}$ & \\
\hline 1917
\end{tabular}

Note. Sources: the design based on Mujta (1997) ${ }^{9}$ and Mujta (1999) ${ }^{10}$.

\footnotetext{
${ }^{9} 635$ lat miasta Kola, Muzeum Technik Ceramicznych (635 years of the city of Kolo. Kolo: Museum of ceramic technique: The cultural society of Kolo), pp. 24-35.

${ }^{10}$ Z dziejów Polskiej Organizacji Wojskowej i Zwiazku Peowiaków na Ziemi Kolskiej (From the history of the Polish Military Organization and the PMO Member Association in the region of Kolo). Koło, pp. 26-27.
} 
The third factor which elevated the level of local culture was the establishment of the Society for Culture and Science in 1901, lobbied by various scientific societies, its founding planted the seeds for the later Poznań Academy.

Over the past several decades, a number of Polish intellectuals, whose daily occupation is the presentation of previous socioeconomic phenomena, have experienced a miraculous oblivion; it has erased the memory of many important, independent market participants. However, this obliteration was defective, as was the thinking behind it. The attempt to efface the facts should be approached very critically. The defectiveness of the attempts to blur the truth may be a source of optimism, as it allows the restoration of precious memories. However, many insightful and continual studies are required for this restoration to become holistic.

The research in that area should be preceded by a thorough investigation of the definition of growth according to one of the economic schools (doctrines) which fully depicts the connection between human psychology and civilisation deriving from the culture sphere identified with a set of values.

\section{Essence of Development in Literature}

Growth as a conceptual and methodological category became the subject of interest for numerous philosophers. Later, it was studied both in the field of natural and social science. Growth and development were intriguing subjects for studies as early as ancient times. In Greece, the notions were described by Xenophanes of Colophon, Aeschylus, Protagoras, Socrates, and Plato, in Rome by Seneca, in Medieval Christianity by St. Augutine, in renaissance by Machiavelli, Morus, Bacon, and others. Among many Enlightment figures, J. J. Rousseau was interested in growth in particular. Rousseau perceived the concept of history as a process of denaturing, which means replacing the natural with the artificial, and at the same time, suppressing emotions with the use of intellect. According to the thinker, nature was a place for those who did not want to take part in the process of denaturing or became its victims (see Table 4).

Table 4

Chosen Concepts of Nature

\begin{tabular}{ll}
\hline Author & Characteristic \\
\hline Aristotle & $(\ldots)$ "nature" is raw material - the matter-being a source of everything what uses the principle of \\
motion and change \\
Thomas of Aquin & "(...) nature we call everything which can incorporate intellect" \\
Kant I. & Area (...) possible experience
\end{tabular}

Note. Source: Balewski and Janowski (2007) ${ }^{11}$.

The concept of "natural man", deriving from the former definitions of nature, was numerously criticized as being ahistorical. Throughout the 18th century and the first half of the 19th century, though growth and development was considered as unidirectional, common, cumulative and taking its inspiration from continuous discovery of freedom. Not until new definition was created by O. Spengler, was the notion differently perceived. In his theory of the civilisation decline, Spengler criticized the theory of linear growth claiming that "The source of every great invention and project is the joy from victory (...) expressing the strong personality, not the utilitarian mass thinking (...)".

${ }^{11}$ Balewski, B., \& Janowski, A. (2007). CSR and the development of a region. In G. Bartkowiak (Ed.), The chances of developing the lands of the western Polish border-Regional and global aspect (p. 59). Higher School of Commerce and Finance in Zielona Gora, Zielona Gora. 
The theory about "civilization decline" enabled to understand that progressive achievements, through inertia, often become the obstacle on the way to progress and growth. Moreover, the concept of cyclical growth was spread, being built on a common saying "the worse, the better".

The concept of cyclical growth outlines that the balance at some respect is reached by cyclical movement, prior to going from one extreme to the other. The opposing views on the idea of linear growth are not predominant which seems to be visible in the characteristics of the notions of growth and progress in other disciplines of social science, including economics (see Table 5).

Table 5

Chosen Characteristics of Economic Definitions of the Notion of Growth (Progress)

\begin{tabular}{|c|c|}
\hline Nurt & Characteristics of the notion of growth \\
\hline $\begin{array}{l}\text { Preclassical } \\
\text { Economy }\end{array}$ & $\begin{array}{l}\text { The basic factors influencing the country growth (economical) and society's well-being are both the } \\
\text { intervention of the government in the process of governing and collecting monetary metals (mercantilism) } \\
\text { and work in agriculture which generates economic surpluss (physiocracy). }\end{array}$ \\
\hline Classical & dispensable condition of nation's wealth (economic growth) is the accumulation of capital. \\
\hline Marxism & $\begin{array}{l}\text { The growth mainly depends on the technology progress. The ideology proved that the consequences of } \\
\text { accumulation of capital are its centralization. It causes discrepancies between a social character of production } \\
\text { and individual embezzlement. }\end{array}$ \\
\hline Institu & $\begin{array}{l}\text { onfiguration of factors, influenced by the innovations which are introduced by entrepreneurs is being } \\
\text { odified. New combinations of economic factors are, comparing with the previous ones, more effective. }\end{array}$ \\
\hline Structuralism & $\begin{array}{l}\text { Socio-economic growth is a series of changes from one structure to the next one; in particular, it is a } \\
\text { transition of a certain structure }(\mathrm{St}) \text { in time }(\mathrm{t}) \text { to the following one }(\mathrm{St}+1) \text { in time }(\mathrm{t}+1) \text { and next from } \\
\text { structure }(\mathrm{St}+1) \text { to structure }(\mathrm{St}+2) \text {; from structure }(\mathrm{St}+2) \text { to structure }(\mathrm{St}+\mathrm{n}) \text {. Growth, therefore, is a } \\
\text { change in social, organizational, or economic structure. Such a change does not require a transition from a } \\
\text { worse condition to a better one. }\end{array}$ \\
\hline Austrian School & $\begin{array}{l}\text { Element of free enterprise" is a leading force of economic growth, and personal property is essential to use } \\
\text { e resources effectively. Governmental interventions in market are always and everywhere destructive. }\end{array}$ \\
\hline
\end{tabular}

Note. Sources: Balewski and Chomicz (2009) ${ }^{12}$, Sadowski and Ostrowski (1978), and Janowski (2014) ${ }^{13}$.

Among economic doctrines, the aspect of determining the growth by “(...) a single, free man who is set in a culture" is mainly stressed by the Austrian School. It states that "An individual, when making a decision and acting according to subjective choices, including individual knowledge and set of values, determines the dynamic and spontaneous socio-economic order, which aims at reaching some balance despite perpetually changing conditions. However, it always fails"14.

Therefore, it is indispensable to do further research on the influence of Russians, Germans, and Jews on the growth of the Eastern Wielkopolska region with the use of the methodological workshop of this school.

\section{References}

Balewski, B., \& Chomicz, W. (2009). CSR and the development of renewable energy. In M. Waszkowiak (Ed.), Renewable energy as future energetic. Personnel Association for Konin (Stowarzyszenie Kadry dla Konina), Konin.

\footnotetext{
12 Balewski, B., \& Chomicz, W. (2009). CSR and the development of renewable energy. In M. Waszkowiak (Ed.), Renewable energy as future energetics. Personnel Association for Konin (Stowarzyszenie Kadry dla Konina), Konin.

${ }_{13}$ Janowski, A. (2014). Economics and practice of human action, the legacy of the Austrian School. In W. Chomicz (Ed.), Towards Economic School (p. 95), Scientific Papers of the Higher School of Personnel Management, Konin.

${ }^{14}$ Kępara, B. (2015). Unpublished "History of economic thought" thesis. Faculty of Economics and Management, Higher School of Personnel Management in Konin, Konin, February 2015.
} 
Balewski, B., \& Janowski, A. (2007). CSR and the development of a region. In G. Bartkowiak (Ed.), The chances of developing the lands of the western Polish border-Regional and global aspect (p. 59). Higher School of Commerce and Finance in Zielona Gora, Zielona Gora.

Janowski, A. (2014). Economics and practice of human action, the legacy of the Austrian School. In W. Chomicz (Ed.), Towards Economic School (p. 95). Scientific Papers of the Higher School of Personnel Management, Konin.

Joskowicz, P. M. (1996). Opowieść o radości i cierpieniu (A tale of joy and suffering) (p. 41). Warszawa: Grupa Image sp. z o.o.

Kępara, B. (2015). History of economic thought. Unpublished thesis, Faculty of Economics and Management, Higher School of Personnel Management in Konin, Konin.

Krische, P., \& Riemann, C. (2014). Die Provinz Posen: Ihre Geschichte und Kultur unter besonderer Berücksichtigung ihrer Landwirtschaft (The Province of Poznan: Their history and culture with special regard to agriculture). Wolfenbüttel: Melchior Verlag.

Mujta, J. St. (1997). 635 years of the city of Koło. Koło: Museum of ceramic technique: The cultural society of Koto (pp. 24-35).

Mujta, J. St. (1999). Z dziejów Polskiej Organizacji Wojskowej i Zwiazku Peowiaków na Ziemi Kolskiej, Koło (From the history of the Polish Military Organization and the PMO Member Association in the region of Koto).

Nietyksza, M. (1986). The development of cities and industrial urban agglomerations in the Kingdom of Poland 1865-1914. Warsaw.

Szulc, S. (1920). Wartość materiałów statystycznych dotyczqcych stanu ludności b. Królestwa Polskiego (The value of statistical material pertaining to the population of the former Kingdom of Poland). Warsaw. 